\title{
Particle size distribution of forages and mixed rations, and their relationship with ration variability and performance of UK dairy herds
}

Article

Accepted Version

Creative Commons: Attribution-Noncommercial-No Derivative Works 4.0

Tayyab, U., Wilkinson, R. G., Reynolds, C. K. and Sinclair, L. A. (2018) Particle size distribution of forages and mixed rations, and their relationship with ration variability and performance of UK dairy herds. Livestock Science, 217. pp. 108-115. ISSN 1871-1413 doi: https://doi.org/10.1016/j.livsci.2018.09.018 Available at https://centaur.reading.ac.uk/79818/

It is advisable to refer to the publisher's version if you intend to cite from the work. See Guidance on citing.

To link to this article DOI: http://dx.doi.org/10.1016/j.livsci.2018.09.018

Publisher: Elsevier

All outputs in CentAUR are protected by Intellectual Property Rights law, including copyright law. Copyright and IPR is retained by the creators or other copyright holders. Terms and conditions for use of this material are defined in the End User Agreement. 


\section{www.reading.ac.uk/centaur}

\section{CentAUR}

Central Archive at the University of Reading

Reading's research outputs online 
1 Particle size distribution of forages and mixed rations, and their

2 relationship with ration variability and performance of UK dairy herds

3 Usama Tayyaba, Robert G. Wilkinsona, Christopher K Reynolds ${ }^{b}$, Liam A.

4 Sinclair ${ }^{*}$

5

6 aDepartment of Animal Production, Welfare and Veterinary Sciences, Harper

7 Adams University, Edgmond, Newport, Shropshire, TF10 8NB, UK.

8 bSchool of Agriculture, Policy and Development, University of Reading, PO Box

9 237, Earley Gate, Reading, RG6 6AR, Berkshire, UK.

10

11 U. Tayyab: utayyab@harper-adams.ac.uk

12 R. G. Wilkinson: rgwilkinson@harper-adams.ac.uk

13 C. K. Reynolds: c.k.reynolds@reading.ac.uk

14 L. A. Sinclair: Isinclair@harper-adams.ac.uk

15

16

17

$18{ }^{*}$ Corresponding author. Liam A. Sinclair

19 E-mail address: Isinclair@harper-adams.ac.uk 


\section{ABSTRACT}

21 The particle size of the ration has been proposed as a key factor, along with its fibre and non-forage carbohydrate concentration, to ensure healthy rumen function and optimal performance of dairy cows. The current particle size

24 distribution recommendations for forages and rations are primarily based on 25 lucerne-haylage and maize silage (MS) and may not be suitable for the wetter grass silage (GS) based rations typically fed in Northern Europe. In order to characterize the particle size distribution of forages and rations in the UK, fifty commercial dairy herds feeding a range of GS and MS based rations were sampled during the winter of $2015 / 2016$. The particle size distribution of the fresh forages and mixed rations (MR; total and partial mixed rations) were analysed using a modified Penn State Particle Separator with six screens of hole size 60, $44,26.9,19,8$, and $4 \mathrm{~mm}$. The fresh MR was collected at 5-equally-spaced locations along the length of the feed-face for each herd within 5-min of feeding to determine the consistency of ration mixing, and again from the same locations 4h post-feeding. Grass silage was the main forage fed on 50 herds, with $80.3 \%$ of the dry matter (DM) being retained above the $19 \mathrm{~mm}$ sieve, which is considerably higher than the North-American recommendations for lucernehaylage. The particle size distribution of MS followed the general recommendations for North American forages, however, the 8-19 $\mathrm{mm}$ fraction was higher and the $<4 \mathrm{~mm}$ lower. The $>60 \mathrm{~mm}$ fraction of the MR had the lowest (0.1\% DM) DM retention, and the 8-19 $\mathrm{mm}$ fraction the highest (34.9\% DM). The MR had a higher proportion of particles retained on the $26.9 \mathrm{~mm}$ sieve when GS was the sole forage. Fifty eight $\%$ of herds were considered to have either moderately or poorly mixed rations, whilst $66 \%$ had evidence of diet selection 
45 (either preferential consumption or selective refusals). Particle size of the MR 46 accounted for $33 \%$ of the variance in the milk fat content and $12 \%$ of milk yield.

47 In conclusion, the particle size distribution of the GS and MR fed on UK dairy 48 herds is different from the current recommendations, suggesting that the particle 49 size of UK dairy rations is too long or new guidelines using additional sieves with 50 larger pore sizes are required. There is also a high proportion of herds with poor 51 mixing and/or evidence of diet selection.

52

Key words:

54 Dairy cows, ration variability, diet selection, particle size distribution

55

\section{Introduction}

57 Feeding dairy cows with a mixed ration (MR; either total or partial mixed ration) is an effective way to provide a homogeneous and balanced diet throughout the day (Coppock et al., 1981). The composition of MR can vary considerably but ryegrass (GS) and maize silages (MS) are the main forages used in the MR fed

61 to dairy herds in Northern Europe (Johansen et al., 2018; March et al., 2014). In

62 order to maintain animal performance and promote a healthy rumen function the inclusion of forages with an adequate particle size and dietary concentration of non-forage carbohydrate (fibre) in the MR are required (Zebeli et al., 2012). The physically effectiveness of a ration has been proposed as the product of the particle size multiplied by its neutral detergent fibre (NDF) content, defined as

67 physically effective fibre (peNDF; Mertens, 1997). Achieving the correct particle size and peNDF in a ration can enhance rumen function leading to an increase in the production of rumen microbes, more efficient degradation of fibre and 
70 increased milk fat content (De Brabander et al., 1999; Zebeli et al., 2012). A short

71 forage particle size is associated with improved compaction in the bunker and can result in reduced aerobic spoilage at feed out (McDonald et al., 1991) and may increase dry matter (DM) intake, due to reduced rumen fill and increased

74 fibre digestibility (Thomson et al., 2017). However, too short a forage particle 75 length can increase the rate of volatile fatty acid production in the rumen, reduce 76 rumination time, and decrease the production of saliva (Tafaj et al., 2007), with 77 the consequence of inhibiting cellulolytic bacteria activity and increasing the risk 78 of sub-acute ruminal acidosis (SARA; Tafaj et al., 2007). In a review of the 79 literature, Zebeli et al. (2012) concluded that too short a particle size (and 80 peNDF), increases the passage rate of digesta and rate of fibre degradation due 81 to a higher surface area for microbial attachment. In contrast, too long a forage particle size may promote ration sorting and result in some cows receiving excess concentrates and others insufficient (Kononoff and Heinrichs, 2003).

84 The estimation of the particle size of forages and MR is problematic, and various 85 methods have been proposed to characterise feed particle distribution using 86 different sieving techniques, with no universally accepted standard. Maulfair and 87 Heinrichs (2012) concluded that the Penn State Particle Separator was the most useful method and proposed dietary guidelines for use on-farm. These recommendations are primarily based on North American rations that consist of 90 MS and lucerne haylage (Eastridge, 2006), and may therefore not be suitable for 91 the typically wetter (e.g. less than 30\% DM) MS and GS commonly fed in Northern 92 Europe (Møller et al., 2000).

93 Heinrichs et al. (1999) reported that processing by the mixer wagon prior to 94 feeding can also have a large effect on the consistency of the mix, and affect the 
particle size and peNDF concentration of the ration subsequently consumed.

96 Mixing protocols have been shown to affect feed intake and milk yield, particularly

97 in rations containing longer chop lengths (Humphries et al., 2010; Maulfair and Henrichs 2010). Consideration should therefore also be given to the effect of particle size and consistency of mixing on the degree of diet selection by dairy cows.

101 The primary objective of the present study was to characterise the particle size 102 distribution and peNDF content of GS, MS and MR fed on UK dairy herds using 103 a modified Penn State Particle Separator, and to compare the observed particle size distribution with current guidelines. The secondary objective of the study was 105 to evaluate the consistency of mixing of MR and extent of sorting of GS and $106 \mathrm{GS} / \mathrm{MS}$ based MR, and to determine the relationship between particle size and 107 cow performance on UK dairy herds.

108

109

\section{Material and methods}

\subsection{Herd characteristics}

111 Fifty commercial dairy herds located throughout the UK (32 in the Midlands of 112 England, 9 in the South of England and 9 in Southwest Scotland) that were feeding GS and/or MS were visited between January and June, 2016. The herds

114 were randomly selected from a database supplied by the Agricultural and 115 Horticultural Development Board, the levy body covering England, Scotland and 116 Wales, with the provision that they were using a MR (partial or total) feeding 117 system and had a high yielding group that contained at least 50 cows. Herds were enrolled onto the study through an initial telephone contact and questionnaire survey to determine suitability and willingness to participate. On the day of the 
120 visit a second questionnaire was completed to collect details of herd 121 characteristics, performance levels and frequencies of fresh feed delivery, feed 122 push up and orts removal. In addition, feeding space per cow, feed mixer make 123 and model, forage harvester make and model, and mixing protocol were 124 recorded. The ingredient composition of MR fed to the target group and the mean 125 concentrate fed in the parlour was also recorded.

126 Out of the 50 herds, 50 fed GS, with 34 using MS in the MR. Other sources of 127 forage being fed were; whole-crop wheat (19), wheat straw (15), fodder beet (5), 128 grass haylage (2), whole-crop triticale (1), whole-crop barley (1), lucerne (1), pea 129 silage (1) and oat silage (1). Forty-four of the herds had an all year around calving 130 pattern, 4 were autumn block calving and 2 spring block calving. Holstein-Friesian 131 was the major breed on 36 herds, with the predominant breed on the remaining 132 herds being Ayrshire (2), Jersey (1), Brown Swiss (1), or (10) having a mixture of 133 Holstein with other breeds (Brown Swiss, New Zealand Friesian, and Jersey) or 134 crossbred. The main feeding system was total MR which was used on 28 herds, 135 while the remaining 22 herds fed a partial MR with additional concentrate fed in 136 the milking parlour. Twenty-four herds used a "tub" type mixer wagon, 18 a 137 "barrel" type, 7 an "auger" design (vertical or horizontal) and one used a forage 138 box.

139 Total herd size ranged from 75 to 2220 animals, with a mean of 354 (Table 1). 140 The number of lactating cows ranged from 67 to 1770 cows/herd, with a mean 141 and median of 310 and 277 , respectively. The annual milk yield ranged from 6000 142 to $12500 \mathrm{~kg} / \mathrm{cow}$, with a mean of $9199 \mathrm{~kg} / \mathrm{cow}$ (median = 9200). Annual energy 143 corrected milk yield (corrected for milk fat and protein; Sjaunja et al., 1991) 144 ranged from 7248 to $13209 \mathrm{~kg} / \mathrm{cow}$, with a mean of $10011 \mathrm{~kg} / \mathrm{cow}$. All herds 
145 delivered fresh feed either once or twice daily, with a mean of 1.3 times/d. Of the

14650 herds, 20 were feeding the MR in a trough where there was no push up the

147 feed. The average frequency of feed push up in the remaining 30 herds was 4.7

148 times/d. The mean orts removal frequency was 4.4 times/wk, with a range from

1490.25 (monthly) to 7 (daily) times/wk. Feed space per cow ranged from 0.30 to

$1500.76 \mathrm{~m} / \mathrm{cow}$, with a mean of $0.56 \mathrm{~m} / \mathrm{cow}$. Length of feed mixing was either

151 manually recorded or provided by the farmer, and ranged from 5 to $60 \mathrm{~min}$. The

152 number of chews per bolus was manually counted for three full bouts for 10 cows

153 randomly selected from the feeding group sampled (Kononoff et al., 2002).

\subsection{Determination of particle size and peNDF distribution of forages and MR}

156 Where more than one feeding group was present, data were collected from the

157 high yielding group in each herd $(n=40)$. Where feed was delivered more than

once $(n=15)$, the first (morning) feed was sampled. The feed face of the high

yielding group of cows (or all cows if no subdivision was present) was divided into

160 five equal sections to determine the consistency of mixing (Sova et al., 2014).

161 Within each feed face section, a $30 \mathrm{~cm} \times 30 \mathrm{~cm}$ quadrat was randomly placed

162 over the MR within 5 mins of fresh feed-out, and all material removed and

163 thoroughly mixed by hand (OhMR; Endres and Espejo, 2010). To determine the

164 level of diet selection (feed sorting), the MR was sampled using the quadrat from

165 the same locations along the feed fence again four hours post feeding (4hMR;

166 Leonardi et al., 2005). Prior to fresh feed delivery, refusals, where available, were

167 also sampled $(n=33)$.

168 The particle size distribution of the forage (GS and MS) and MR samples were 169 analysed on both a fresh and dried basis. A modified Penn State Particle 
170 Separator with four screens of $26.9,19,8$, and $4 \mathrm{~mm}$ was used to determine the 171 particle size of GS and GS/MS based MR, and three screens of 19, 8 and $4 \mathrm{~mm}$

172 for MS according to the manual shaking procedure described by Kononoff et al.

173 (2003). Perennial ryegrass (Lolium perenne) and MS (Zea mays L.) were 174 sampled from first, second or third cut GS and MS silage bunkers as described 175 by Sinclair (2006) and the particle size measured using the modified Penn State 176 Particle Separator described above. The particle size distribution (\%) was 177 calculated by dividing the weight of each fraction by the sum of all fractions and 178 multiplying by 100 .

179 The on-farm particle size distribution analysis using one additional Penn State 180 Particle Separator sieve screen $(26.9 \mathrm{~mm})$ was found to be inadequate to 181 accurately determine the geometric mean particle size $\left(\mathrm{X}_{\mathrm{m}}\right)$ of $\mathrm{GS}$ and GS based 182 MR. Consequently, two larger sieve screens of size 44 and $60 \mathrm{~mm}$ were used to 183 reanalyse particle size of OhMR and GS using frozen and defrosted samples. The 184 frozen samples were thawed at room temperature for $6 \mathrm{~h}$ prior to analysis.

\subsection{Chemical analysis}

187 The DM content (AOAC, 2012; 988.05) of each fraction of OhMR, 4hMR, refusals, 188 GS and MS for each herd was determined by oven drying at $105^{\circ} \mathrm{C}$ to constant 189 weight. Forage and MR samples were then milled in a hammer mill (Crompton 190 Control Series 2000, Wakefield West Yorkshire UK) fitted with a $1 \mathrm{~mm}$ screen. 191 The crude protein (988.05; Dumas method [ $\mathrm{N} \times 6.25]$ ), ash $\left(942.05\right.$; at $550^{\circ} \mathrm{C}$ for $1926 \mathrm{~h}$ ) and ether extract (920.39) was analysed as described by AOAC (2012). The 193 NDF (using sodium sulphite and heat stable amylase, and expressed residual of 194 ash) and acid detergent fibre (ADF) content was analysed according to Van Soest 
et al. (1991). The starch content of the OhMR was analysed by Trouw Nutrition

196 (Blenheim House, Blenheim Road, Ashbourne, Derbyshire, UK) using the 197 procedure described by McCleary et al. (1997).

\subsection{Calculations and statistical analysis}

200 Energy corrected milk yield $(\mathrm{kg})$ was calculated as: milk yield $(\mathrm{kg}) \times[(38.3 \times$ fat $201(\mathrm{~g} / \mathrm{kg})+24.2 \times$ protein $(\mathrm{g} / \mathrm{kg})+15.71 \times$ lactose $(\mathrm{g} / \mathrm{kg})+20.7) / 3,140]$, as described 202 by Sjaunja et al. (1991). The geometric mean particle size $\left(X_{m}\right)$ was calculated 203 using the method described by ANSI (1992). The physical effectiveness factor 204 (pef) was determined as the DM proportion of particles longer than $8 \mathrm{~mm}$ 205 (pef $>8 m m$ ) or 4 mm (pef $>4 m m$, Lammers et al., 1996; Maulfair and Heinrichs, 2010). 206 The peNDF>4mm was calculated by multiplying the NDF content (\% DM) of the MR 207 by the $p e f_{>4 m m}$, and $p e N D F_{>8 m m}$ by multiplying the NDF content (\% DM) of the MR 208 by the $\operatorname{pef}_{>8 \mathrm{~mm}}$ (Lammers et al., 1996; Mertens, 1997).

209 The consistency of ration mixing of each herd was calculated using the co210 efficient of variation (CV\%) of each particle size fraction of the OhMR (Buckmaster 211 et al., 2014; Oelberg and Stone, 2014; Sova et al., 2014), with a CV of $>5 \%$ 212 considered significant (Silva-del-Rio and Castillo, 2012). The CV of each fraction 213 was weighted for the respective percentage particle size distribution and then the 214 corrected CV summed. Herd-level diet selection was calculated for each fraction 215 by dividing the proportion (DM basis) at OhMR by the corresponding proportion 216 at $4 \mathrm{hMR}$ and refusals, and presented as a percentage. A sorting value of $100 \%$ 217 indicated no sorting, $<100 \%$ indicated preferential consumption, and $>100 \%$ 218 indicated selective refusal. 
219 All data were summarised by herd and tested for normality using the general 220 descriptive statistics component of GenStat 17.1 ( (VSN International Ltd.,

221 Oxford, UK). Associations between measures of productivity (energy corrected 222 milk yield, milk fat $\mathrm{g} / \mathrm{kg}$, milk protein $\mathrm{g} / \mathrm{kg}$ ), feeding management and ration 223 characteristics were analysed using a standard linear model (i.e. ANOVA) with 224 forage source and shaking technique as fixed effects and herds and location as 225 random effects. A linear regression model was used to determine the association 226 between $X_{m}$ and energy corrected milk yield and milk fat using GenStat $17.1 \AA$ 227 (VSN International Ltd., Oxford, UK). For multiple comparisons, all fractions of 228 the mixed ration were analysed by general ANOVA followed by a Tukey test, with 229 the significant level set at $P<0.05$.

230

231

\section{Results}

232

3.1. Forage proximate and physical characteristics

233 The mean DM of the GS was $23 \mathrm{~g} / \mathrm{kg}$ lower $(P=0.022)$ and the CP $54 \mathrm{~g} / \mathrm{kg} \mathrm{DM}$ 234 higher than the MS (Table 2). The NDF and ADF content were also 65 and 64 $235 \mathrm{~g} / \mathrm{kg}$ DM higher in the GS than the MS $(P<0.001)$. The highest \% DM retention 236 of GS was the $26.9-44 \mathrm{~mm}$ fraction $(51.6 \%, P<0.001)$, with the majority of the 237 DM (80.3\%) being longer than $19 \mathrm{~mm}$. In contrast, the highest retention of DM for 238 MS was between $8-19 \mathrm{~mm}(73.2 \%, P<0.001)$. The $X_{m}, p e N D F_{>4 m m}$ and $239 p e N D F_{>8 m m}$ content was higher $(P<0.001)$ in GS than MS (mean values of 42.6 240 and $10.5 \mathrm{~mm}, 48$ and $40 \%$, and 47 and $34 \%$ for $X_{m}, p e N D F_{>4 m m}$ and $p e N D F_{>8 m m}$ 241 for GS and MS respectively). 


\subsection{Mixed ration proximate and physical characteristics}

244 The mean forage to concentrate ratio across the 50 herds was $77: 23$ on a fresh 245 weight basis, and 57:43 on a DM basis, with a GS to MS ratio on the 34 herds 246 that fed both forages of 50:50 (fresh weight basis) or 48:52 (DM basis; Table 3).

247 The DM concentration of the MR ranged from 213 to $544 \mathrm{~g} / \mathrm{kg}$, with a mean value 248 of $373 \mathrm{~g} / \mathrm{kg}$ across the 50 herds, whilst the mean CP ranged from 116 to $205 \mathrm{~g} / \mathrm{kg}$ 249 DM, with a mean value of $160 \mathrm{~g} / \mathrm{kg}$ DM. The mean and median NDF 250 concentration of the MR was 391 and $381 \mathrm{~g} / \mathrm{kg}$ DM respectively. For the MR, the 251 lowest proportion of DM was retained on the $60 \mathrm{~mm}$ fraction $(P<0.001)$, with the $2528-19 \mathrm{~mm}$ fraction having the highest proportion $(P<0.001)$, and there was no 253 difference $(P>0.05)$ between the $44-60$ and $19-26.9 \mathrm{~mm}$ fractions. The 254 peNDF $>4 m m$ concentration of the MR ranged from 22 to $47 \%$ with a mean of $33 \%$, 255 and the mean $p e N D F_{>8 m m}$ was $73 \%$. The mean $X_{m}$ of the MR was $19.5 \mathrm{~mm}$, 256 ranging from 6.2 to $44.9 \mathrm{~mm}$. The starch concentration of MR ranged from 63 to $257237 \mathrm{~g} / \mathrm{kg} \mathrm{DM}$ with a mean value of $138 \mathrm{~g} / \mathrm{kg} \mathrm{DM}$. The mean DM of the $0 \mathrm{~h}, 4 \mathrm{~h}$ and 258 refusals did not differ $(P=0.10)$ between sampling times, and the DM 259 concentration of the various fractions of MR did not change over time $(P>0.05$; 260 data not shown).

261 Herds that fed GS as the main forage had a higher $(P<0.01)$ proportion of the 262 DM retained on the $26.9-44 \mathrm{~mm}$ fraction of the OhMR compared to those that 263 used a mixture of GS and MS (Table 4). In contrast, herds that used a mixture of 264 both forages had a higher $(P<0.01)$ proportion of the DM retained on the 8-19 265 $\mathrm{mm}$ fraction. The type of mixer wagon (barrel, tub or auger) had no effect $(P>$ 0.05 ) on the particle size distribution of any fraction of the OhMR (data not shown). 267 When the partial or total MR were considered separately, the proportion of longer 
268 fractions $(26.9-44$ and $44-60 \mathrm{~mm})$ was higher $(P<0.05)$ when in the partial MR, 269 while the shorter fractions $(8-19,4-8$ and $<4 \mathrm{~mm})$ were highest $(P<0.05)$ when 270 fed as a total MR (Supplementary Table S1).

271

272 3.3. Variability in mixed ration mixing

273 The coefficient of variation of mixing of MR was highest for the 19-26.9 and >26.9 $274 \mathrm{~mm}$ fractions at 15 and $13.7 \%$ respectively, while the minimum $\mathrm{CV}$ of $6.4 \%$ was 275 for the 8-19 $\mathrm{mm}$ fraction (Table 5). The type of wagon mixer, forage source, total $276 \mathrm{MR}$ or partial MR, and $\mathrm{X}_{\mathrm{m}}$ had no effect $(P>0.05)$ on ration variability across all 277 five fractions (data not shown).

278

279 3.4. Particle size distribution of mixed rations post-feeding and diet selection

280 Diet selection calculated between $0-4 \mathrm{~h}, 4-24 \mathrm{~h}$ and $0-24 \mathrm{~h}$, demonstrated that 281 there was selective refusal of the $>26.9$ and $19-26.9 \mathrm{~mm}$ fractions and a 282 preferential consumption of the 8-19, 4-8 and $<4 \mathrm{~mm}$ fractions between $0-24 \mathrm{~h}$ 283 period (Table 6), although there was considerable variation between herds. 284 Sorting activity calculated between 0 and 4 h showed preferential consumption $(P$ $285<0.001)$ for the $4-8$ and $8-19 \mathrm{~mm}$ fraction of the MR while the $>26.9,19-26.9$ and $286<4 \mathrm{~mm}$ fractions were selectively refused. The inclusion of whole-crop wheat ( $\mathrm{n}$ $287=19)$ and straw $(\mathrm{n}=15)$, the mixer wagon type or $X_{m}$ had no effect $(P>0.05)$ on 288 the level of feed sorting (data not shown).

289

290 3.5. Association between particle size and production

291 There was a positive relationship $\left(R^{2}=0.33 ; P=0.004\right)$ between $X_{m}$ and mean 292 milk fat content $(\mathrm{g} / \mathrm{kg})$ across all herds (Figure 1). The relationship was improved 
when Holstein-Friesian and Holstein-Friesian crosses were analysed separately $294\left(R^{2}=0.36 ; P<0.001\right)$, with the $R^{2}$ being highest when Holstein-Friesian herds were analysed alone, with almost $50 \%$ of the variation in milk fat content between herds being accounted for by $X_{m}\left(R^{2}=0.47 ; P<0.001\right)$. In contrast, there was a negative relationship between $X_{m}$ and energy corrected milk across the 50 dairy 298 herds, accounting for $16 \%$ of the variation $(P<0.001)$.

299

300

\subsection{Fresh vs dried particle size distribution}

When dried prior to separation there was a difference in particle size distribution,

with less long material and more short material than when measured fresh and 303 then dried (Table 7 and Supplementary Table S2). For GS the $>26.9 \mathrm{~mm}$ fraction 304 decreased $(P<0.001)$, while the $8-19,4-8$ and the $<4 \mathrm{~mm}$ fractions increased $(P$ $305<0.001$ ) when analysed in a dried form. Similarly, the $4-8$ and $<4 \mathrm{~mm}$ fractions of 306 the MS increased $(P<0.001)$ when analysed in a dried compared to a wet form.

307 For the MR, the proportion of the $>26.9 \mathrm{~mm}$ decreased $(P<0.001)$, while the 308 proportion of the $4-8$ and the $<4 \mathrm{~mm}$ fractions increased $(P<0.01)$ when analysed 309 in a dried form compared to fresh and then dried.

\section{Discussion}

\subsection{Herd characteristics and proximate analysis}

313 The mean annual milk yield and herd size recorded in the current study were 314 higher than the values reported for the UK (yield of $8180 \mathrm{~kg}$ and $143 \mathrm{cows} /$ herd, 315 respectively; AHDB, 2016). This difference may be due in part to the selection 316 criteria for the current study, with all herds recruited feeding MR and using GS, 317 MS or a mixture as the main forage source. As a consequence, spring calving, 
318 grazed grass based herds that have a lower mean milk yield (AHDB, 2016; Garcia 319 and Holmes, 1999) were not used, although the trend in the UK is for more 320 continuous housing, indoor feeding rather than grazing (March et al., 2014).

321 The MS being fed in the current study had a lower DM content at $300 \mathrm{~g} / \mathrm{kg}$ 322 compared to the $395 \mathrm{~g} / \mathrm{kg}$ reported by Lammers et al. (1996) in the northeast of 323 the United States of America (USA). The nutrient composition of the GS used in 324 the current study was, however, typical of European ryegrass silage (Møller et 325 al., 2000), with a mean CP of $136 \mathrm{~g} / \mathrm{kg}$ DM and NDF of $492 \mathrm{~g} / \mathrm{kg}$ DM. The mean forage to concentrate ratio of the MR in the current study (57:43 DM basis) was 327 higher than that reported for 50 herds in Minnesota (52:48, Endres and Espejo, 328 2010). A higher forage to concentrate ratio is more likely to maintain an efficient 329 rumen function and should minimise the risk of SARA (Zebeli et al., 2012). 330 However, twenty four out of the 50 herds fed a lower proportion of forage in the 331 MR than the minimum of $56 \%$ proposed by Zebeli et al. (2012), and may 332 subsequently have been at risk of SARA.

333 The average DM of the MR in the current study of $373 \mathrm{~g} / \mathrm{kg}$ was lower than that 334 reported by Eastridge (2006) and Sova et al. (2013) for typical North American 335 rations. In similar cross-sectional studies, Sova et al. (2013) reported a mean total 336 MR DM of $477 \mathrm{~g} / \mathrm{kg}$ in 22 Canadian herds, while Endres and Espejo (2010) 337 reported a mean of $523 \mathrm{~g} / \mathrm{kg}$ DM in the total MR of 50 herds in Minnesota, USA. 338 Rations with a high DM content may increase DM intake, but may also encourage 339 cows to sort (Leonardi et al., 2005). The CP content of the MR in the current study 340 was also lower compared to that of 50 herds in the USA ( $175 \mathrm{~g} / \mathrm{kg} \mathrm{DM}$; Endres 341 and Espejo, 2010) or 22 herds in Canada (165 g/kg DM; Sova et al., 2013). This 342 difference may be due to the greater use of concentrates and lower use of forages 
343 in North American rations as reflected in the lower forage to concentrate ratio

344 (Endres and Espejo, 2010). The average NDF content of the MR in the current 345 study was approximately $90 \mathrm{~g} / \mathrm{kg}$ DM higher than that reported in the USA (298 $346 \mathrm{~g} / \mathrm{kg}$ DM; Endres and Espejo, 2010) or Canadian rations (313 g/kg DM; Sova et 347 al., 2013). This was probably due to the greater use of forage in the current study, 348 especially GS, which has a higher NDF concentration than MS or lucerne haylage 349 (Hoffman et al., 1993), but may also be affected by maturity at harvesting which 350 increases NDF concentration (Dawson et al., 2002). The higher concentration of 351 NDF in the MR along with a sufficient particle size are associated with a more 352 efficient rumen function for fibre degrading microbiota by resisting a depression 353 in rumen pH (Zebeli et al., 2012). Similarly, the ADF content was approximately $35450 \mathrm{~g} / \mathrm{kg}$ DM higher in the current study compared to that fed in the USA (198 $\mathrm{g} / \mathrm{kg}$ 355 DM; Endres and Espejo, 2010) or Canadian rations (205 g/kg DM; Sova et al., 356 2013), but was typical of Northern European rations (Johansen et al., 2018).

\subsection{Ration physical characteristics}

359 The particle size distribution of MS followed the general guidelines suggested by 360 Heinrichs (2013) of 3-8\% above $19 \mathrm{~mm}, 45$ to $65 \%$ between $8-19 \mathrm{~mm}, 20$ to $30 \%$ between 4 and $8 \mathrm{~mm}$, and $<10 \%$ below $4 \mathrm{~mm}$ although the $8-19 \mathrm{~mm}$ fraction of MS in the current study was higher than that reported by Maulfair et al. (2010).

363 This difference may be due to the higher moisture content of MS used in the UK 364 that promotes the adherence of shorter particles, but may also reduce sorting 365 (Leonardi et al., 2005). Overall, the particle size distribution of MS in the UK was similar to the current guidelines for MS based on North America rations, and consequently, there is little requirement for additional research or separate 
recommendations for UK and northern European MS. Out of the 50 herds used

369 in the current study, the minimum \% DM of GS retained on the $>19 \mathrm{~mm}$ sieve 370 was $49 \%$, considerably higher than the $10-20 \%$ guidelines for lucerne haylage in 371 the USA (Heinrichs, 2013). Feeding a longer particle size may result in a higher 372 rumen $\mathrm{pH}$ and avoid SARA, but is also associated with a reduction in feed intake 373 due to a greater rumen fill (Tafaj et al., 2007; Zebeli et al., 2012).

374 The mean particle size distribution of the OhMR in the current study differed from 375 the guidelines based on North American rations (Heinrichs, 2013), with the long 376 (>19 mm) particle size distribution being $38 \%$, approximately $50 \%$ higher than 377 that reported by Sova et al. (2013), DeVries et al. (2011) or Hosseinkhani et al. 378 (2008), and approximately 4 times higher than that reported by Heinrichs (2013), 379 Endres and Espejjo (2010), Miller-Cushon and DeVries (2009), or Heinrichs and 380 Kononoff, (1996) (Supplementary Table S3). The difference in particle size 381 distribution of MR in the current study reflected the high inclusion of GS that 382 contained a very long particle size $\left(>19 \mathrm{~mm}=80 \% \mathrm{DM}, \mathrm{X}_{\mathrm{m}}=42.6 \mathrm{~mm}\right)$. The use 383 of other forages (e.g. whole-crop wheat, wheat straw, fodder beet) in the MR in 384 the current study did not significantly affect the particle size distribution of the MR, 385 and supports that the high proportion of GS in the ration was the major factor causing the differences. The higher proportion of the 26.9-44 and 8-19 mm 387 particle fractions in the MR may also be explained by the high moisture content, 388 as $4-8$ and $<4 \mathrm{~mm}$ particles may have adhered to longer particles (Leonardi et 389 al., 2005). However, the considerably longer particle size of GS than lucerne 390 haylage based MR suggests that either the particle size of UK dairy rations is too 391 long or the need for more specific particle size measurement methods and 392 distribution recommendations when wetter GS is the major forage in the MR. 
393 When GS was the sole forage in the MR, rations had a higher proportion of the 394 26.9-44 and 44-60 $\mathrm{mm}$ fractions which may promote ration sorting (DeVries et al., 2007), although in the current study there was no relationship between Xm and degree of sorting after 4 or $24 \mathrm{~h}$. The additional $26.9,44$ and $60 \mathrm{~mm}$ pore size sieves used in the Penn State Particle Separator in the current study allowed a more even distribution of particle size for GS and MR samples than the 399 traditional Penn State Particle Separator. However, as a very small proportion of 400 particles was retained on the $19-26.9 \mathrm{~mm}$ screen, a screen larger than $26.9 \mathrm{~mm}$ 401 may be more appropriate.

402

\section{4.3. Variability in ration mixing}

404 Feeding MR is an effective method to provide all the required nutrients to dairy 405 cows, and a properly mixed ration ensures a uniform delivery of all feed ingredient to the animal (Coppock et al., 1981). Mixer wagons and mixing protocols can 407 however, influence particle size distribution and result in differences in feed intake 408 and milk yield, particularly for rations with longer chop lengths (Humphries et al., 409 2010). Heinrichs et al. (1999) also reported that processing by the mixer wagon 410 prior to feed-out can have a large effect on the particle size and peNDF 411 subsequently fed and the consistency of the mix. In a survey of Iranian herds, 412 Esmaeili et al. (2016) reported a high variability (CV >10\%) in particle size 413 distribution of MR with the highest variation recorded for the $>19 \mathrm{~mm}$ fraction, a 414 finding in agreement with the current study. There were $42 \%$ of herds that had a 415 CV $\leq 5 \%$ (indicating a well-mixed ration), $26 \%$ that had a CV of between $5-10 \%$ 416 (moderately mixed), and $32 \%$ that had a CV $>10 \%$ (poorly mixed ration). There 417 was no effect of mixer model on overall ration variability across all herds. In 
418 contrast, Heinrichs et al. (1999) reported that MR processing by the mixer wagon

419 can have a significant effect on the ration consistency, particle size and peNDF 420 concentrations of the ration subsequently consumed.

421

\section{4.4. Herd level diet selection}

423 Herd level diet selection was calculated as the proportional change in each 424 fraction of the MR over time post-feeding. Feed sorting activity is usually associated with the preferential consumption of fine starch or protein rich particles in the ration (DeVries et al., 2007). However, in the current study, there were

427 selective refusals for the $>19 \mathrm{~mm}$ fraction and preferential consumption for the $428<8 \mathrm{~mm}$ fraction. To more easily determine the variability of diet selection across 429 herds, the long fractions (>60, 44-60, 26.9-44 and 19-26.9 mm) were summed 430 (>19 $\mathrm{mm})$, and the short $(4-8$ and $<4 \mathrm{~mm})$ fractions summed $(<8 \mathrm{~mm})$, while assuming that a sorting value of $100 \% \pm 5$ indicated no sorting, $>105 \%$ indicated

432 selective refusal and a sorting value of $<95 \%$ indicates preferential consumption.

433 Of the 50 herds, $82 \%$ had either selective refusal or did not show preferential 434 consumption for the $>19 \mathrm{~mm}$ fraction which may be associated with the inclusion 435 of long particles of GS. There was no sorting activity observed for the $<8 \mathrm{~mm}$ 436 fraction in $46 \%$ of the herds. As discussed previously, this may have been due to 437 the comparatively high moisture content of the MR in the current study that 438 caused the cohesion of smaller particles to larger particles making it more difficult 439 to sort (Beauchemin, 1991; Fish and DeVries, 2012; Leonardi et al., 2005). 


\subsection{Associative effects of particle size and production}

442 Several authors have reported a relationship between peNDF and milk 443 performance (Tafaj et al., 2007; Zebeli et al., 2012). In the current study there

444 was also a positive relationship between $p e N D F_{>4 m m}$ or peNDF $>8 \mathrm{~mm}$ and milk fat 445 content $\left(\mathrm{R}^{2}=0.14\right.$ and $\mathrm{R}^{2}=0.16 ; P<0.01$, respectively), but these were not as 446 strong as with $X_{m}$, although due to the nature of the data caution should be 447 exercised when interpreting the results. The positive relationship between $\mathrm{X}_{\mathrm{m}}$ and 448 milk fat content, and the negative relationship with milk yield is in agreement with 449 De Brabander et al. (1999). A long fibrous particle size is associated with an 450 increase of acetic acid production in the rumen that can subsequently lead to a 451 higher milk fat content (Merten, 1997). Alternatively, a higher fibre ration may 452 increase rumen $\mathrm{pH}$ and reduce the ruminal production of trans-10, cis-12 453 conjugated linoleic acid that has been associated with milk fat reduction 454 (Harvatine and Bauman, 2011). Contrary to our findings, Tafaj et al. (2007) 455 reported no correlation between particle size and milk yield or milk components 456 and suggested that any effect of particle size on milk yield mainly depends on its 457 influence on DM intake, which was not measured in the current study.

4.6. Comparison of fresh and dry separation

460 Compared with when measured fresh, the particle size distribution of dried 461 forages and MR differed, with the proportion of longer fractions decreasing while 462 short fractions increased after drying of samples (Kononoff et al., 2003). This 463 difference may be attributed to the wetter forages and rations used resulting in 464 adherence of short particles to larger particles, or the physical reduction in particle 465 size due to the shaking when undertaken dry. It is therefore recommended to 
466 partially or completely dry the forages and MR before analyses in order to

467 overcome the moisture variation (Heinrichs, 2013). However, this may not be a 468 practical way of measuring particle size of wetter forages and MR on-farm.

469

\section{5. Conclusions}

471 The particle size distribution of GS and MR based on GS in UK dairy herds was

472 found to be considerably higher than current guidelines that are based on North

473 American forages and rations. This suggests that the particle size of UK dairy

474 rations is either too long, or that new guidelines or methods of particle size

475 evaluation for GS and GS/MS based MR in Northern Europe are required. The

476 poor consistency of mixing and high degree of selection recorded on the majority

477 of herds is of concern, and further research into reasons for this variation and its

478 impact on cow performance is required. Finally, the high use of concentrates by

$47950 \%$ of the herds in the current study is a potential threat to SARA and reiterates

480 the need for more appropriate means of particle size characterisation and 481 guidelines for wetter, GS based dairy rations, with further controlled studies 482 required to determine the optimal particle size distribution of these rations.

\section{Acknowledgments}

485 This research was financed by AHDB. The authors would like to thank S. Parsons 486 and G. Vince for helping in the modification of Penn State Particle Separator and 487 A. Harrison for assistance with data collection. 


\section{References}

489 AHDB, 2016. Statistics of UK dairy industry. http://dairy.ahdb.org.uk/marketinformation/\#.V4zZrfkrKUk (accessed 18 July 2016).

ANSI, (American National Standards Institute), 1992. ANSI/ASAE S424.1 MAR1992 (R2012): Method of determining and expressing particle size of chopped forage materials by screening. St. Joseph, MI: ASAE.

AOAC. 2012. Official methods of analysis, $19^{\text {th }}$ Ed. AOAC Int., Washington DC.

Beauchemin, K.A., 1991. Ingestion and mastication of feed by dairy cattle. Vet. Clin. N. Am-Food A. 7, 439-463.

497 Buckmaster, D.R., Wang, D., Wang, H., 2014. Assessing uniformity of total mixed 498 rations. Appl. Eng. Agric. 30, 693-698.

499 Coppock, C.E., Bath, D.L., Harris, B., 1981. From feeding to feeding systems. J. 500 Dairy Sci. 64, 1230-1249.

501 Dawson, L.E.R., Kirkland, R.M., Ferris, C.P., Steen, R.W.J., Kilpatrick, D.J., 502 Gordon, F.J., 2002. The effect of stage of perennial ryegrass maturity at 503 harvesting, fermentation characteristics and concentrate supplementation, 504 on the quality and intake of grass silage by beef cattle. Grass and Forage 505 Sci. 57, 255-267.

506 De Brabander, D.L., De Boever, J.L., Vanacker, J.M., Boucque, Ch.V., 507 Botterman, S.M., 1999. Evaluation of physical structure in dairy cattle 508 nutrition. In: Garnsworthy, P.C., Wiseman, J. (Eds.), Recent Advances in $509 \quad$ Animal Nutrition. Nottingham University Press, pp. 111-145.

510 DeVries, T.J., Beauchemin, K. A., Von Keyserlingk, M.A.G., 2007. Dietary forage 511 concentration affects the feed sorting behavior of lactating dairy cows. J. 512 Dairy Sci. 90, 5572-5579. 
513 DeVries, T.J., Holtshausen, L., Oba, M., Beauchemin, K.A., 2011. Effect of parity

514 and stage of lactation on feed sorting behavior of lactating dairy cows. J.

515 Dairy Sci. 94, 4039-4045.

516 Eastridge, M.L., 2006. Major Advances in Applied Dairy Cattle Nutrition. J. Dairy 517 Sci. $89,1311-1323$.

518 Endres, M.I., Espejo, L.A., 2010. Feeding management and characteristics of 519 rations for high-producing dairy cows in freestall herds. J. Dairy Sci. 93, 822520829.

521 Esmaeili, M., Khorvash, M., Ghorbani, G.R., Nasrollahi, S.M. and Saebi, M., 522 2016. Variation of TMR particle size and physical characteristics in 523 commercial Iranian Holstein dairies and effects on eating behaviour, 524 chewing activity, and milk production. Livest. Sci. 191, $22-28$.

525 Fish, J.A., DeVries, T.J., 2012. Short communication: Varying dietary dry matter 526 concentration through water addition; Effect on nutrient intake and sorting of

528 Garcia, S.C., Holmes, C.W., 1999. Effects of time of calving on the productivity 529 of pasture-based dairy systems: A review. New. Zeal. J. Agr. Res. 42, 347362.

531 Harvatine. K.J., Bauman, D.E., 2011. Characterization of the acute lactational 532 response to trans-10, cis-12 conjugated linoleic acid. J. Dairy Sci. 94, 60475336056.

534 Heinrichs, A.J., Buckmaster, D.R., Lammers, B.P., 1999. Processing, mixing and 535 particle-size reduction of forages for dairy cattle. J. Anim. Sci. 77, 180-186. 536 Heinrichs, J., 2013. The Penn State Particle Separator. Penn State University. 537 http://extension.psu.edu/animals/dairy/nutrition/forages/forage-quality- 
539 Hoffman, P.C., Sievert, S.J., Shaver, R.D., Welch, D.A., Combs, D.K., 1993. In 540 situ dry matter, protein, and fiber degradation of perennial forages. J. Dairy $541 \quad$ Sci. $76,2632-2643$.

542 Hosseinkhani, A., DeVries, T.J., Proudfoot, K.L., Valizadeh, R., Veira, D.M., von $543 \quad$ Keyserlingk, M.A.G., 2008. The effects of feed bunk competition on the feed $544 \quad$ sorting behavior of close-up dry cows. J. Dairy Sci. 91, 1115-1121.

545 Humphries, D.J., Beever, D.E., Reynolds, C.K., 2010. Adding straw to a total mixed ration and the method of straw inclusion affects production and eating behaviour of lactating dairy cows. Proceedings of the British Society of Animal Science and Agricultural Research Forum, page 95.

549 Johansen, M., Lund, P., Weisbjerg, M.R., 2018. Feed intake and milk production 550 in dairy cows fed different grass and legume species: a metaanalysis. Animal 12, 66-75.

552 Kononoff, P.J, Lehman, H., and Heinrichs, A., 2002. Technical note- A 553 comparison of methods used to measure eating and ruminating activity in $554 \quad$ confined dairy cattle. J. Dairy Sci. 85, 1801-1803.

555 Kononoff, P.J., Heinrichs, A.J., Buckmaster, D.R., 2003. Modification of Penn 556 State forage and total mixed ration particle separator and the effects of 557 moisture content on its measurements. J. Dairy Sci. 86, 1858-1863.

558 Lammers, B.P., Buckmaster, D.R., Heinrichs, A.J., 1996. A simple method for the 559 analysis of particle sizes of forage and total mixed rations. J. Dairy Sci. 79, $560 \quad 922-928$.

561 Leonardi, C., Giannico, F., Armentano, L.E., 2005. Effect of water addition on 562 selective consumption (sorting) of dry diets by dairy cattle. J. Dairy Sci. 88 , 
1043-1049.

564 March, M.D., Haskell, M.J., Chagunda, M.G.G., Langford, F.M., Roberts, D.J., 565 2014. Current trends in British dairy management regimens. J. Dairy Sci. 97, 566 7985-7994.

567 Maulfair, D.D., Heinrichs, A.J., 2010. Technical note: Evaluation of procedures 568 for analyzing ration sorting and rumen digesta particle size in dairy cows. J. $569 \quad$ Dairy Sci. 93, 3784-3788.

570 Maulfair, D.D., Heinrichs, A.J., 2012. Methods to measure forage and diet particle 571 size in the dairy cow. Prof. Anim. Sci. 28, 489-493.

572 Maulfair, D.D., Zanton, G.I., Fustini, M., Heinrichs, A.J., 2010. Effect of feed 573 sorting on chewing behavior, production, and rumen fermentation in lactating 574 dairy cows. J. Dairy Sci. 93, 4791-4803.

575 McCleary, B.V., Gibson, T.S., Mugford, D.C., 1997. Measurement of total starch 576 in cereal products by amyloglucosidase-a-amylase method: Collaborative 577 study. J. AOAC Int. 80, 571-579.

578 McDonald P., Henderson, A.R., Heron, S.J.E., 1991. The Biochemistry of Silage. $579 \quad 2^{\text {nd }}$ edition. Chalcombe Publications, Marlow, Bucks, UK.

580 Mertens, D.R., 1997. Creating a system for meeting the fiber requirements of 581 dairy cows. J. Dairy Sci. 80, 1463-1481.

582 Miller-Cushon, E.K., DeVries, T.J., 2009. Effect of dietary dry matter 583 concentration on the sorting behavior of lactating dairy cows fed a total 584 mixed ration. J. Dairy Sci. 92, 3292-3298.

585 Møller, J., Thøgersen, R., Kjeldsen, A., Weisbjerg, M.R., Søegaard, K., 586 Hvelplund, T., Børsting, C.F., 2000. Feedstuff tables. (English version) The $587 \quad$ NationalCommittee on Cattle Husbandry, Report no. 91. 
588 Oelberg, T.J., Stone, W., 2014. Monitoring total mixed rations and feed delivery systems. Vet. Clin. N. Am-Food A. 30, 721-744.

590 Silva-del-Rio, N., Castillo, A.R., 2012. Degree of agreement between the ration 591 formulated and the ration fed on seven California dairies. J. Dairy Sci. 95, 592 (E. Suppl. 2):579. (Abstr.).

593 Sinclair, L.A., 2006. Effect of sample position within a clamp on the nutritive value 594 of fermented and urea-treated whole crop wheat. Proceedings of the British 595 Society of Animal Science, 44.

596 Sjaunja, L.O., Baevre, L., Junkkarinen, L., Pedersen, J., Setala, J., 1991. 597 Measurement of the total energy content of cow's milk and the energy value $598 \quad$ of milk fat and milk protein. Eaap Public, 50, 52-155.

599 Sova, A.D., LeBlanc, S.J., McBride, B.W., DeVries, T.J., 2013. Associations 600 between herd-level feeding management practices, feed sorting, and milk 601 production in freestall dairy farms. J. Dairy Sci. 96, 4759-4770.

602 Sova, A.D., LeBlanc, S.J., McBride, B.W., DeVries, T.J., 2014. Accuracy and 603 precision of total mixed rations fed on commercial dairy farms. J Dairy $604 \quad$ Sci. $97,562-571$.

605 Tafaj, M., Zebeli, Q., Baes, C., Steingass, H., Drochner, W., 2007. A meta606 analysis examining effects of particle size of total mixed rations on intake,

607 rumen digestion and milk production in high-yielding dairy cows in early 608 lactation. Anim. Feed Sci. Tech. 138, 137-161.

609 Thomson, A.L., Humphries, D.J., Jones, A.K., Reynolds, C.K., 2017 The effect 610 of varying proportion and chop length of lucerne silage in a maize silage611 based total mixed ration on diet digestibility and milk yield in dairy cattle. 612 Animal, 11, 2211-2219. 
613 Van Soest P.J., Robertson J.B., Lewis B.A., 1991. Methods for dietary fiber, 614 neutral detergent fiber, and nonstarch polysaccharides in relation to animal 615 nutrition. J. Dairy Sci. 74, 3583-3597.

616 Zebeli, Q., Aschenbach, J.R., Tafaj, M., Boghun, J., Ametaj, B.N., Drochner, W., 617 2012. Review: Role of physically effective fiber and estimation of dietary 618 fiber adequacy in high-producing dairy cattle. J. Dairy Sci. 95, 1041-1056. 
619 Figure captions

620

621 Figure 1. Relationship between mean particle size of $M R\left(X_{m}, m m\right)$ and milk fat $622(\mathrm{~g} / \mathrm{kg} / \mathrm{herd})$ across 50 herds containing Holstein Friesian (HF; $\bullet=36$ ), Ayrshire $623(\boldsymbol{\Lambda}=2)$, Jersey $(+=1)$, Brown Swiss $(\boldsymbol{m}=1)$ and Holstein crossbred (HFX; $\bullet=10)$. 624

625 Figure 2. Relationship between mean particle size of MR $(\mathrm{Xm}, \mathrm{mm})$ and energy 626 corrected milk (ECM; Sjaunja et al., 1991) across 50 herds containing Holstein 627 Friesian (HF; $\bullet=36)$, Ayrshire $(\boldsymbol{\Lambda}=2)$, Jersey $(\boldsymbol{+}=1)$, Brown Swiss $(\boldsymbol{\bullet}=1)$ and 628 Holstein crossbred (HFX; $\bullet=10)$. 